\title{
The Use of Accounting Policy Options under IFRS in Europe: Do Country, Industry, and Topic Factors Matter?
}

\author{
Karsten Eisenschmidt ${ }^{1}$ and Joanna Krasodomska ${ }^{2}$
}

ABSTRACT

\begin{abstract}
Since the formation of the International Accounting Standards Board (IASB), the use of International Financial Reporting Standards (IFRS) has spread and they have become global standards for financial reporting. However, they are not used unanimously all over the world. This paper focuses on differences in countries' approaches to IFRS. Our study aims to investigate the use of accounting policy choice for selected options in Europe with a particular focus on countries, industry and topic-specific firm factors. We analyze financial statements of 416 companies of the STOXX Europe 600 operating in 17 European countries. We use content analysis to identify the companies' decisions to choose a particular option allowed under IFRS and run a logistic regression to identify potential factors that influence them. Our findings suggest that the factors under investigation do not always have a significant influence on the accounting option choice. However, the country variables seem to have a stronger influence than industry or topic variables. The study contributes to the body of literature mainly because it investigates a uniform European setting with the use of the 2017 data and it covers countries not included in previous studies. Its results also provide a basis for discussion on the financial statements quality and the impact of IFRS across countries.
\end{abstract}

KEY WORDS: Accounting choice, IFRS, international differences, Europe, accounting harmonization.

JEL Classification: M41, M48.

IInstitute of Accounting and Auditing, Kiel University of Applied Sciences, Sokratesplatz 2, D-24149 Kiel, Germany

2Department of Financial Accounting, Cracow University of Economics, ul. Rakowicka 27, 31-510 Kraków, Poland

\section{Introduction}

Accounting policy choice is made by the company when it decides to select an approach (option) over another approach or approaches on a particular accounting topic. The options are included in the accounting standards. Making such choices is a part of the corporate accounting policy and it is communicated in the annual report (Nobes \& Stadler, 2015). Accounting policy options under International Fi-

Correspondence concerning this article should be addressed to: Joanna Krasodomska, Department of Financial Accounting, Cracow University of Economics, ul. Rakowicka 27, 31-510 Kraków, Poland. E-mail: joanna.krasodomska@uek.krakow.pl nancial Reporting Standards (IFRS) have a long, wellestablished, and widely accepted tradition. As Nobes (2006) notes, in the early 1990s, options in IFRS were common because many standards had been written before 1989 when the Framework was published, and also because the International Accounting Standards Committee (IASC) operated on the basis of the need for a $75 \%$ majority of votes of its Board members. Due to the fact that these members came from diverse backgrounds and were subject to political pressure, one way of passing a standard was to insert options. These IFRS options have been progressively removed. In 1993, many options were highlighted by the IASC 
with the label "benchmark treatment" and "allowed alternative", indicating the more and less preferred approaches of the IASC. It is worth noting that the International Accounting Standards Board (IASB) has not continued this labelling practice for any new or revised standards.

Given the above, the presence of the accounting options seems justified, despite being somewhat contradictory with the main aim of the accounting harmonization which is to provide financial reporting users with economic information which is comparable across companies. As Jaafar and McLeay (2007) point out: "accounting is harmonized when all firms operating in similar circumstances adopt the same accounting treatment for similar transactions regardless of their domicile" (p. 156). Accounting options and their use by companies due to non-economic reasons - despite the fact that the decisions are to some extent limited - hampers the worldwide accounting harmonization and is clearly contrary to the IASB ambition (Guermazi \& Khamoussi, 2018).

Accounting is influenced by the economic and social environment. Therefore, researchers aim to provide new insights into the accounting practices and their consequences by exploring how economic, social, cultural and legal factors are relevant to their development (Albu \& Albu, 2014). This paper explores the use of accounting policy choice by European firms with a particular focus on how they are influenced by countries, industry and topic-specific firm factors. The results of the research allow stating that some of the analyzed accounting options are uniformly used in Europe. That strengthens comparability of financial data which is one major qualitative characteristic of an accounting system. However, there are still accounting options, which are treated differently by the preparers. Comparability is missing for those choices.

It has been shown that country factors are particularly important, as companies decide to continue the pre-IFRS practice by choosing a similar allowed option under IFRS (Kvaal \& Nobes, 2010). Industry factors and topic factors were also found as relevant for management's decision-making (e.g., Klumpes \& Whittington, 2003; Morris \& Gordon, 2006), as well as firms characteristics (e.g., Aledo et al., 2009;
Jafaar \& McLeay, 2007). Despite the presence of the accounting options choice topic in the accounting literature, we believe that there is still room for the scientific inquiry, and some further questions might be answered.

Our study aims to investigate the use of accounting policy choice for selected options in Europe with a particular focus on countries, industry and topic-specific firm factors. Our final sample consists of 416 companies included in the STOXX Europe 600 representing ten different industries and operating in 17 countries of the European region. We use the financial statements for fiscal year 2017 and content analysis method to identify how companies use accounting options. We run a logistic regression to analyze the factors that might influence their policy choices.

The empirical findings are as follows. Descriptive analysis results let us identify five accounting options clearly preferred by preparers, namely: a two statement approach for its total comprehensive income, an indirect method for operating cash flow, dividend paid in finance cash flow, valuation of property, plant and equipment as well as intangibles at cost. This outcome allows supporting the assumption that the accounting harmonization in European region is in progress. However, seven accounting options out of 12 included in our analysis were not used by companies in the same way. Further analysis of the factors influencing the firms' choices regarding these options revealed that country, industry and topic variables do not always have a significant influence on the accounting option choice. However, the country variables seem to have a stronger influence than the others. Therefore, we were able to confirm the results of some other studies, for example, Stadler and Nobes (2014).

We believe that our paper contributes to the literature on accounting choice and international accounting in several ways. Firstly, we cover more countries with our analysis that any other study we are familiar with. We focus on 17 European countries, while the highest number of countries so far investigated by Lourenco et al. (2015) was 14. Secondly, our sample is relatively large and faces no big sample bias as previous studies (e.g., Stadler \& Nobes, 2014). We have 416 firms in our sample, 
while 10 out of 15 other studies we refer to in our paper used data samples with less than 400 companies. Also, in some cases, when the sample was large, the number of accounting issues investigated was low (e.g., Jafaar \& McLeay, 2007; Christensen \& Nikolaev, 2013). The STOXX Europe 600 represents large, mid and small capitalization companies across Europe. Therefore, the risk of facing a big sample bias is low. Thirdly, our analysis is based on relatively new data, since we used financial information for the fiscal year 2017, and last study we are familiar with (Lourenco et al., 2015) was based on the financial statements for the fiscal year 2013. Fourthly, our research covers countries not included in previous studies namely: Czech Republic, Finland, and Luxembourg.

The paper is organized as follows. Section 2 presents a literature review and hypotheses development. Section 3 describes the data and methodology. The study results are presented and discussed in Section 4. The last section contains conclusions, along with research limitations and suggestions for further investigation.

\section{Literature Review and Hypotheses Development}

A significant number of studies addressing the subject of accounting options have been published (Table 1).

The papers on the accounting policy options (Table 1) were published in years 2007-2015 with the use of the data set ranging from the year 1991 to 2013. Christopher Nobes is the author the most involved in the topic. He is the author or co-author of seven studies out of 15 mentioned above. The number of countries under investigation varies from one (Damaria \& Dufour, 2007; Aledo et al., 2009; Bahadir \& Tolga, 2013; Eisenschmidt \& Schwenkler, 2016) to 14 (Lourenco et al., 2015). Four Western European countries were most often investigated, namely United Kingdom (in 12 studies), Germany (in 11), France and Spain (both in ten studies). They were followed by Australia, which was covered by 8 studies. Other countries less often included in the sample were: Italy (in six studies), Switzerland (in four), Sweden, South Africa, Hong Kong and China (each of them in three studies), Belgium, Denmark, the Netherlands (each of them in two research papers). Austria, Turkey, Norway, Poland, Russia, Ireland, Portugal, Canada and South Korea were included in only one of the studies referred to in the Table 1, solo or as a part of a wider sample. The countries, which were most often included together in the empirical part of the papers (as a group), were: Australia, France, Germany, Spain, and United Kingdom. The largest sample regarding the number of companies under investigation was used in Christensen and Nikolaev (2013) study. They analyzed the IFRS reports of 1,539 firms. The smallest sample was the one included in the Aledo et al. (2009) paper only 88 Spanish firms. However, at the same time, this study covers the largest number of accounting issues - 32. Nine out of the remaining 13 studies used data samples with less than 400 companies, and only four were based on bigger samples. As far as the topics are concern, apart from the Aledo et al. (2009) paper mentioned above, five studies focused on 16 topics and four studies on three issues. Other researchers concentrated on 9, 11, 13, 14 or 15 accounting topics.

The conducted literature review, and in particular, the findings presented by Stadler and Nobes (2014) allow us to expect that country, industry and topic-specific firm factors might influence the policy choice under IFRS.

The literature suggests that country-specific factors, such as legal and taxation systems, corporate financing system, or institutional setting in general influence the country accounting system and at the same time cause differences in IFRS policy choice. Where IFRS includes an option, there was presumably at least some international variation in either rules or practices, because otherwise a choice would not have been included in the international standard. Despite IFRS being global, financial statements' preparers are still local. Before using IFRS, firms had to use domestic accounting requirements, which sometimes offered the same options as IFRS (Stadler \& Nobes, 2014). Local accounting rules (nationally-based pre-IFRS practices) influence accounting policy choices. Therefore, we can still separate Europe into an Anglo European group 
Table 1

Selected Research on the IFRS Accounting Policy Options

\begin{tabular}{|c|c|c|c|c|c|}
\hline $\begin{array}{l}\text { Author } \\
\text { (publication } \\
\text { year) }\end{array}$ & $\begin{array}{l}\text { Research object (coun- } \\
\text { try) }\end{array}$ & $\begin{array}{l}\text { Data set } \\
\text { year(s) }\end{array}$ & Sample & $\begin{array}{l}\text { Accounting options } \\
\text { investigated }\end{array}$ & Main findings \\
\hline $\begin{array}{l}\text { Jaafar and } \\
\text { McLeay (2007) }\end{array}$ & $\begin{array}{l}\text { Austria, Belgium, Germany, } \\
\text { Denmark, Spain, Finland, } \\
\text { France, Ireland, Italy, } \\
\text { Portugal, Sweden, United } \\
\text { Kingdom }\end{array}$ & $\begin{array}{l}\text { 1991, 1995, } \\
1999\end{array}$ & $\begin{array}{l}1991-541 \text { firms, } \\
1995-673 \text { firms } \\
\text { and } 1999-698 \\
\text { firms }\end{array}$ & $\begin{array}{l}\text { Three accounting issues } \\
\text { (invento-ry costing meth- } \\
\text { od, de-preciation } \\
\text { of fixed as-sets, goodwill } \\
\text { on consolida-tion) }\end{array}$ & $\begin{array}{l}\text { According to the study re-sults, country } \\
\text { where the company is based and sec-tor of } \\
\text { operations are signifi-cant determinants in } \\
\text { ac-counting policy choice. However, coun- } \\
\text { try differ-ences are still far greater than } \\
\text { sector differences; listing status and size } \\
\text { are significantly influence the accounting } \\
\text { policy choice. }\end{array}$ \\
\hline $\begin{array}{l}\text { Demaria and } \\
\text { Dufour (2007) }\end{array}$ & France & 2005 & $\begin{array}{l}107 \text { firms } \\
\text { included in SBF } \\
120 \text { index }\end{array}$ & $\begin{array}{l}\text { Three ac-counting is-sues } \\
\text { (related to the fair value } \\
\text { meas-urement) }\end{array}$ & $\begin{array}{l}\text { Findings show that the ma-jority of French } \\
\text { companies maintained the historical cost } \\
\text { for the valuation of assets, which is the } \\
\text { con-servative option. The fair value adop- } \\
\text { tion is influenced by the finance industry } \\
\text { membership, and it is not linked with size, } \\
\text { financial leverage, CEO's compensa-tion, } \\
\text { institutional ownership and cross-listing. }\end{array}$ \\
\hline $\begin{array}{l}\text { Aledo et al. } \\
\text { (2009) }\end{array}$ & Spain & 2004 and 2005 & 88 firms & 32 accounting issues & $\begin{array}{l}\text { The results suggest that Spanish listed } \\
\text { groups apply more conservative criteria } \\
\text { to limit the number of changes they intro- } \\
\text { duce related to the Spanish GAAP. Firms } \\
\text { in consumer services, consumer goods, oil } \\
\text { and gas, } \\
\text { and basic materials, manu-facturing and } \\
\text { construction industries introduce the larg- } \\
\text { est number of adjust-ments. Such firms' } \\
\text { charac-teristics as industry, size, auditor's } \\
\text { opinion and capi-tal structure, play an im- } \\
\text { portant role in explaining the probability to } \\
\text { adopt the optional accounting ap-proach } \\
\text { provided by the IFRS. }\end{array}$ \\
\hline $\begin{array}{l}\text { Kvaal and } \\
\text { Nobes }(2010)\end{array}$ & $\begin{array}{l}\text { Australia, France, Germany, } \\
\text { Spain, United Kingdom }\end{array}$ & $\begin{array}{l}\text { 2005/2006 } \\
\text { (financial } \\
\text { year started in } \\
2005 \text { ) }\end{array}$ & $\begin{array}{l}\text { Largest listed } \\
\text { companies; } 232 \\
\text { IFRS reports }\end{array}$ & 16 accounting issues & $\begin{array}{l}\text { The study findings provide significant evi- } \\
\text { dence that pre-IFRS national practice con- } \\
\text { tinues where this is allowed within IFRS. }\end{array}$ \\
\hline Nobes (2011) & $\begin{array}{l}\text { Australia, France, Germany, } \\
\text { Spain, United Kingdom, Italy, } \\
\text { Netherlands, Sweden }\end{array}$ & $\begin{array}{l}\text { 2008/2009(fi- } \\
\text { nancial year } \\
\text { started in } \\
\text { 2008) }\end{array}$ & 287 IFRS reports & 13 accounting issues & $\begin{array}{l}\text { According to the research results, Anglo } \\
\text { and Continental European groupings can } \\
\text { be differentiated in the IFRS practices of } \\
\text { very large companies. What is more, study } \\
\text { findings show that, despite } 30 \text { years of har- } \\
\text { monization, the two main classification } \\
\text { groups are the same as they were in } 1980 \text {. }\end{array}$ \\
\hline
\end{tabular}




\section{Table 1}

Selected Research on the IFRS Accounting Policy Options (Continued)

\begin{tabular}{|c|c|c|c|c|c|}
\hline $\begin{array}{l}\text { Author } \\
\text { (publication } \\
\text { year) }\end{array}$ & $\begin{array}{c}\text { Research object } \\
\text { (country) }\end{array}$ & $\begin{array}{l}\text { Data set } \\
\text { year(s) }\end{array}$ & Sample & $\begin{array}{c}\text { Accounting } \\
\text { options inves- } \\
\text { tigated }\end{array}$ & Main findings \\
\hline $\begin{array}{l}\text { Cairns, Mas- } \\
\text { soudi, Taplin, } \\
\text { \& Tarca, (2011) }\end{array}$ & Australia, United Kingdom & 2005 & $\begin{array}{l}228 \text { large listed } \\
\text { companies }\end{array}$ & $\begin{array}{l}\text { Three accounting } \\
\text { issues (related to the } \\
\text { fair value measure- } \\
\text { ment). }\end{array}$ & $\begin{array}{l}\text { The results suggest that most companies } \\
\text { follow conservative approach and/or do } \\
\text { not have motivations to use fair value } \\
\text { measurement. }\end{array}$ \\
\hline $\begin{array}{l}\text { Kvaal and } \\
\text { Nobes (2012) }\end{array}$ & $\begin{array}{c}\text { Australia, France, } \\
\text { Germany, Spain, United } \\
\text { Kingdom }\end{array}$ & $\begin{array}{l}\text { 2005/2006 (data } \\
\text { tak-en from } \\
\text { Kvaal and Nobes } \\
\text { (2010) study) and } \\
2008 / 2009 \\
\text { (financial year } \\
\text { start-ed in 2008) }\end{array}$ & $\begin{array}{l}\text { Largest listed } \\
\text { companies; } 232 \\
\text { IFRS reports } \\
\text { from } 2005 / 2006 \\
\text { and } 210 \text { IFRS } \\
\text { reports from } \\
2008 / 2009\end{array}$ & 16 accounting issues & $\begin{array}{l}\text { Authors find that, despite some changes } \\
\text { in some coun-tries, national patterns ob- } \\
\text { served in the first IFRS fi-nancial state- } \\
\text { ments had persisted into subsequent peri- } \\
\text { ods. Australian and UK companies made } \\
\text { few policy changes. French and Span-ish } \\
\text { companies made more changes than the } \\
\text { other companies. What is more, they } \\
\text { also made more changes after transition } \\
\text { than at transition, which means that they } \\
\text { moved away from previous national prac- } \\
\text { tices, thereby increasing interna-tional } \\
\text { comparability. }\end{array}$ \\
\hline $\begin{array}{l}\text { Nobes and Per- } \\
\text { ramon (2013) }\end{array}$ & $\begin{array}{c}\text { Australia, France, } \\
\text { Germany, Spain, United } \\
\text { Kingdom }\end{array}$ & $\begin{array}{l}\text { 2008/2009(finan- } \\
\text { cial year started in } \\
\text { 2008) }\end{array}$ & $\begin{array}{l}155 \text { large and } \\
155 \text { small listed } \\
\text { companies }\end{array}$ & 15 accounting issues & $\begin{array}{l}\text { Study results reveal signifi-cant differ- } \\
\text { ences between the IFRS policy choices of } \\
\text { small and large companies. Small compa- } \\
\text { nies make more ho-mogeneous choices } \\
\text { within a country than large compa-nies. } \\
\text { IFRS policy choice diversification de- } \\
\text { pends on the topic. For some topics, } \\
\text { nearly all the listed compa-nies based in a } \\
\text { country made the same choice. However, } \\
\text { on other topics, the variety of approaches } \\
\text { was observed. }\end{array}$ \\
\hline $\begin{array}{l}\text { Nobes and } \\
\text { Stadler (2013) }\end{array}$ & $\begin{array}{l}\text { Australia, France, } \\
\text { Germany, Italy, Spain, } \\
\text { United Kingdom, South } \\
\text { Africa, Switzerland, } \\
\text { Canada, South Korea, } \\
\text { Hong Kong, China }\end{array}$ & 2011 & $\begin{array}{c}514 \text { largest listed } \\
\text { companies; 5,689 } \\
\text { policy choices }\end{array}$ & 14 accounting issues & $\begin{array}{l}\text { The research findings pro-vide evidence of } \\
\text { sectoral differences in IFRS policy choice } \\
\text { on certain topics. The authors identified } \\
\text { two-group classification of coun-tries } \\
\text { depending on the coun-tries, sectors and } \\
\text { topics. This classification was in line with } \\
\text { the counties' groups identified according } \\
\text { to the common/code law ap-proach. }\end{array}$ \\
\hline $\begin{array}{l}\text { Christensen } \\
\text { and Nikolaev } \\
\text { (2013) }\end{array}$ & Germany, United Kingdom & 2005 or 2006 & 1,539 firms & $\begin{array}{l}\text { Three accounting } \\
\text { issues (related to the } \\
\text { fair value measure- } \\
\text { ment) }\end{array}$ & $\begin{array}{l}\text { Authors find a very limited use of fair val- } \\
\text { ue accounting. With very few exceptions, } \\
\text { they find that fair value is used exclusively } \\
\text { for proper-ty. Findings also indicate that } \\
\text { institutional differences are important de- } \\
\text { terminants of the choice to use fair value. }\end{array}$ \\
\hline
\end{tabular}


Table 1

Selected Research on the IFRS Accounting Policy Options (Continued)

\begin{tabular}{|c|c|c|c|c|c|}
\hline $\begin{array}{l}\text { Author } \\
\text { (publication } \\
\text { year) }\end{array}$ & $\begin{array}{l}\text { Research object (coun- } \\
\text { try) }\end{array}$ & $\begin{array}{l}\text { Data set } \\
\text { year(s) }\end{array}$ & Sample & $\begin{array}{l}\text { Accounting options } \\
\text { investigated }\end{array}$ & Main findings \\
\hline $\begin{array}{l}\text { Haller and } \\
\text { Wehrfritz } \\
\text { (2013) }\end{array}$ & Germany, United Kingdom & $\begin{array}{c}2005 \text { and } \\
2009\end{array}$ & 310 firms & 16 accounting issues & $\begin{array}{l}\text { The results indicate that IFRS policy choice } \\
\text { differs between Germany and the UK if } \\
\text { particular local ap-proach under GAAP is } \\
\text { dif-ferent. Most firms, when selecting IFRS } \\
\text { options, tend to choose the accounting poli- } \\
\text { cies required by national rules and interna- } \\
\text { tional dif-ferences in financial report-ing } \\
\text { are likely to continue under IFRS. }\end{array}$ \\
\hline $\begin{array}{l}\text { Bahadir and } \\
\text { Tolga (2013) }\end{array}$ & Turkey & 2005 & 235 firms & 11 accounting issues & $\begin{array}{l}\text { Study results reveal that companies select } \\
\text { different IFRS accounting policy options } \\
\text { concerning meas-urement model for plant, } \\
\text { property and equipment and investment } \\
\text { property. Re-garding intangible assets the } \\
\text { revaluation model is not used in practice. }\end{array}$ \\
\hline $\begin{array}{l}\text { Stadler and } \\
\text { Nobes (2014) }\end{array}$ & $\begin{array}{c}\text { Australia, Switzerland, China, } \\
\text { Germany, Spain, France, } \\
\text { United Kingdom, Hong } \\
\text { Kong, Italy, South Africa }\end{array}$ & 2008 & $\begin{array}{l}323 \text { firms; 4,537 } \\
\text { policy choices }\end{array}$ & 16 accounting issues & $\begin{array}{l}\text { According to the authors, country factors } \\
\text { have the greatest influence on IFRS policy } \\
\text { choice. They are particularly important } \\
\text { when the IFRS accounting policy choice } \\
\text { does not affect an important accounting } \\
\text { num-ber. Industry and topic fac-tors influ- } \\
\text { ence the choice on some topics. }\end{array}$ \\
\hline $\begin{array}{l}\text { Nobes and } \\
\text { Stadler (2015) }\end{array}$ & $\begin{array}{l}\text { Australia, Switzerland, China, } \\
\text { Germany, Spain, France, } \\
\text { United Kingdom, Hong } \\
\text { Kong, Italy, South Africa }\end{array}$ & 2005 to 2011 & $\begin{array}{l}514 \text { large firms } \\
40,895 \text { policy } \\
\text { choices }\end{array}$ & 16 accounting issues & $\begin{array}{l}\text { According to the study find-ings, the ma- } \\
\text { jority of reasons for the accounting policy } \\
\text { changes refer to qualitative characteristics } \\
\text { (QCs) of financial information as presented } \\
\text { in the IASB con-ceptual framework. QCs } \\
\text { are more often referred to if the change } \\
\text { relates to measure-ment and are positively } \\
\text { associated with company's size and country } \\
\text { transpar-ency. }\end{array}$ \\
\hline $\begin{array}{l}\text { Lourenco et al. } \\
\text { (2015) }\end{array}$ & $\begin{array}{c}\text { France, Germany, Italy, } \\
\text { Netherlands, Spain, Sweden, } \\
\text { United Kingdom, Belgium, } \\
\text { Denmark, Finland, Norway, } \\
\text { Poland, Russia, Switzerland }\end{array}$ & 2013 & 300 firms & Nine accounting issues & $\begin{array}{l}\text { According to the authors, pre-IFRS ac- } \\
\text { counting differences influence the account- } \\
\text { ing options used by companies after the } \\
\text { IFRS implementation. }\end{array}$ \\
\hline $\begin{array}{l}\text { Eisenschmidt } \\
\text { and Schwen- } \\
\text { kler (2016) }\end{array}$ & Germany & 2013 & 146 firms & 11 accounting issues & $\begin{array}{l}\text { The results show a homogeneous use of } \\
\text { some accounting options (e.g. cost model } \\
\text { for property, plant and equipment) and } \\
\text { industry specific influences (e.g. fair value } \\
\text { measurement of investment properties for } \\
\text { real estate companies). The analyzed com- } \\
\text { panies rarely used the option for an early } \\
\text { adoption of IFRS } 10,11 \text {, and } 12 \text {. }\end{array}$ \\
\hline
\end{tabular}


and a Continental European group despite the level of standardization resulting from the IFRS (Nobes, 2011). What is more, according to Stadler and Nobes (2014) management will be especially likely to continue with local pre-IFRS practice if the choice does not affect an important accounting number. Therefore, the country effect will be especially visible, for example, regarding the use of indirect vs. direct method for operating cash flow. In this case, although the choices on this topic affect the appearance of the financial statements, no important accounting number changes. Given the above, we formulate the first hypothesis as follows:

H1: Country factors influence the European companies IFRS policy choice.

There is also evidence that industry affects the IFRS accounting choice. Industry factors are the shared characteristics within an industry, such as the business model (Stadler \& Nobes, 2014). There are economic differences between industries, and certain topics have varying relevance by industry (Jaafar \& McLeay, 2007). Stadler and Nobes (2014) assumed that the industry effect would be more visible with regard to such topics as income statement presentation (by nature or by function) or the use of FIFO method (versus weighted average). For example, according to the results of Jaafar and McLeay (2007) study, the information technology sector is predominantly FIFO-based. Their findings also indicate that a firm belonging to a resources-based industry has the highest odds of employing more than one inventory method. These findings are consistent with the fact that the FIFO method has provided a reasonable description of inventory movements in the case of information technology. Therefore, we derive our second hypothesis:

H2: Industry factors influence the European companies IFRS policy choice.

Previous research has found that topic factors influence accounting choice. An example of an IFRS policy topic is the presentation of operating flows in the cash flow statement; the IFRS policy options are the direct and indirect methods, and a policy choice is a selection made by a particular firm (Stadler \& Nobes, 2014). We follow Stadler and Nobes (2014) who state that "management will only make a different choice from other firms in the same country and industry if the specific circumstances of the firm are materially different from those of other firms. Just as an industry can have features which make it unusual in its country, so a firm can have features which make it unusual within its country or industry" (p. 395). Kvaal and Nobes (2010) showed that there is no variation within countries on some topics, that is, all firms in a country make the same choice. Low withincountry variation and high between-country variation on a particular topic imply that country factors are particularly influential on IFRS policy choice. This situation will occur where pre-IFRS international differences (which were either due to precise pre-IFRS national requirements or to predominant national practice despite options) survive under IFRS. Therefore, the following third hypothesis is put forward:

H3: Topic factors influence the European companies IFRS policy choice.

\section{Data and Methodology}

We are interested in the use of accounting options in Europe because previous studies mainly focus on other jurisdictions and regions (e.g., Stadler \& Nobes, 2014) or analyze certain countries (e.g., Eisenschmidt \& Schwenkler, 2016). We focus our analysis on the companies of the STOXX Europe 600 which represents large, mid and small capitalization companies across 17 countries of the European region. This has several advantages. (1) We get a very broad sample of different European countries which helps us to analyze potential country effects. (2) Besides the country, we are also interested in analyzing industry-specific uses of accounting options. The STOXX Europe 600 also offers a broad company selection out of different industries. (3) We have a size-independent sample because the STOXX Europe 600 includes large, mid and small capitalization companies of the European 
region. That helps to avoid a big sample bias and allows further insights besides the previous results for large companies. Stadler and Nobes (2014) focus for example on the major stock market index of selected countries and could face out of this selection a big sample bias.

We analyze the financial statements for fiscal year 2017. We only focus on one year because accounting policy choices are sticky over time, rather than being independent observations (Kvaal \& Nobes, 2012). The STOXX Europe 600 composition as of 31st December 2017 is the starting point for our sample. There are several issues which lead to a sample reduction. (1) According to previous studies (e.g., Stadler \& Nobes, 2014; Eisenschmidt \& Schwenkler, 2016), we exclude companies of the financial industry because of their specific business model. (2) Our content analysis was done in April and May 2018. Therefore, we had to exclude companies with a fiscal year which is not the calendar year because of missing data for the fiscal year 2017. (3) For some companies, we could not find the financial statements on the internet or we only got financial statements which present data derived by another accounting system (e.g., local GAAP instead of IFRS). These companies were also excluded from our analysis. In sum, we have a final sample of 416 European companies (Table 2).

We have 17 European countries in our sample. That are Austria (AT), Belgium (BE), Czech Republic (CZ), Denmark (DK), Finland (FI), France (FR), Germany (DE), Ireland (IE), Italy (IT), Luxembourg (LU), Netherlands (NL), Norway (NO), Portugal (PT), Spain (ES), Sweden (SE), Switzerland (CH) and United Kingdom (GB). The abbreviation of the country follows ISO 3166-1 alpha-2 code. Some of these countries (AT, CZ, LU and PT) have only a low number of observations and are in comparison to the other countries underrepresented. Therefore, the results for these countries are not representative. Table 3 shows the country and industry distribution. The industry classification follows the STOXX Europe 600 classification (supersector). In sum, we have 10 different industries in our sample. The distribution of companies in the industries shows that certain industries (e.g., industrials or consumer discretionary) have substantially higher amounts of observations but there is no industry which has a too low number of observations. The minimum amount per industry amounts to 19 companies (telecommunication). Therefore, an industry-specific analysis is possible.

We used content analysis (Krippendorff, 2012) to evaluate the companies' use of accounting options. The data was hand-collected by six coders. All financial statements were analyzed regarding our identified accounting options and dichotomously coded. Our identified accounting options are not relevant for all of our 416 companies, that is, not every company has investment properties and therefore cannot apply the fair value measurement option in IAS 40 . If we cannot find information regarding an accounting option in the financial statements, we coded that as not applicable and eliminated that company in the analysis for the specific accounting option. Therefore, we have a different number of observations for the individual analysis of the accounting options. To assure reliability, we implemented controls in the coding process. Every fifth data point of each coder had to be reviewed from one of the other five coders. In total, $20.19 \%$ of the manual compiled data were checked in terms of correct coding. We did not find substantial differences between the coding of the different coders. Additionally, randomly selected observations were reviewed by one of the authors. Overall, we can assure intercoder reliability (Lombard et al., 2002) for our content analysis.

We run a logistic regression to analyze the potential influence factors. The dependent variable is the use of a specific option and the independent variables follow our derived research hypotheses. The country and the industry variables enter as dummy variables into the regression. We follow the work of Stadler and Nobes (2014) in the use of the topic variables. The specific topic variable will be deflated by sales if it relates to a flow statement and by total assets if it relates to the balance sheet. Additionally, Stadler and Nobes (2014) ranked the specific topic variables and formed 10 groups. Afterwards, they assigned for each group scores in the range from 1 to 10 . The lowest value group assigns point 1 and the largest value group point 10 . This approach has the advantage that you avoid problems with highly skewed data or extreme observations (outlier problems) and also alleviates problems with endogeneity in the regression analysis (Stadler \& Nobes, 2014). The topic 
Table 2

Sample Size and Reductions

\begin{tabular}{lccccccccccc}
\hline Country & AT & BE & CZ & DK & FI & FR & DE & IE & IT & LU & NL \\
\hline Index constituents on 31/12/2017 & 7 & 15 & 2 & 22 & 17 & 89 & 75 & 9 & 32 & 3 & 27 \\
Excluded: & & & & & & & & & & & \\
Financials & 2 & 4 & 1 & 4 & 1 & 11 & 7 & 2 & 11 & 0 & 5 \\
Balance sheet date not year end & 2 & 1 & 0 & 0 & 0 & 4 & 0 & 1 & 0 & 0 & 0 \\
No audited IFRS financial statements & 0 & 0 & 0 & 0 & 0 & 3 & 1 & 0 & 1 & 0 & 0 \\
No financial statements & 0 & 0 & 0 & 0 & 0 & 4 & 1 & 0 & 0 & 0 & 1 \\
\hline Companies & $\mathbf{3}$ & $\mathbf{1 0}$ & $\mathbf{1}$ & $\mathbf{1 8}$ & $\mathbf{1 6}$ & $\mathbf{6 7}$ & $\mathbf{6 6}$ & $\mathbf{6}$ & $\mathbf{2 0}$ & $\mathbf{3}$ & $\mathbf{2 1}$ \\
\hline
\end{tabular}

Table 2

Sample Size and Reductions (Continued)

\begin{tabular}{lccccccc}
\hline Country & NO & PT & ES & SE & CH & GB & SUM \\
\hline Index constituents on 31/12/2017 & 12 & 3 & 27 & 43 & 49 & 168 & 600 \\
Excluded: & & & & & & & \\
Financials & 3 & 0 & 8 & 8 & 11 & 32 & 110 \\
Balance sheet date not year end & 0 & 0 & 0 & 1 & 2 & 36 & 47 \\
No audited IFRS financial statements & 0 & 0 & 2 & 0 & 7 & 2 & 16 \\
No financial statements & 0 & 0 & 0 & 0 & 0 & 5 & 41 \\
\hline Companies & $\mathbf{9}$ & $\mathbf{3}$ & $\mathbf{1 7}$ & $\mathbf{3 4}$ & $\mathbf{2 9}$ & $\mathbf{9 3}$ & \\
\hline
\end{tabular}

Note: This table shows the sample selection per country. The countries are Austria (AT), Belgium (BE), Czech Republic (CZ), Denmark (DK), Finland (FI), France (FR), Germany (DE), Ireland (IE), Italy (IT), Luxembourg (LU), Netherlands (NL), Norway (NO), Portugal (PT), Spain (ES), Sweden (SE), Switzerland (CH), United Kingdom (GB).

variables stem from Datastream/Worldscope and are displayed in Appendix B. The regression analysis also includes two controls. We use size (natural logarithm of market capitalization as of 31st of December 2017) and dividend yield as of 31st of December 2017 as proxy for growth prospects. Both variables are not based on accounting numbers to avoid problems of endogeneity. The use of an accounting option can lead to a change of an accounting number, for instance, using the revaluation model (IAS 16) will lead to higher total assets if the fair value is higher than the book value. In that case, using total assets (an accounting number) as a measure for size would lead to endogeneity in the model. As a further robustness check, we also use the natural logarithm of the companies' revenues for the period 2017 as a proxy for size in the regression models. This variable is not influenced by capital market participants, is also used in previous empirical studies as proxy for size (e.g., Inchausti 1997, p. 57) and will not be altered by the use of our analyzed accounting options.

The regression analysis for each accounting option has the following general form:

\section{OPTION\# $\#_{i}=\alpha+\beta_{1}$ country $_{i}+\beta_{2}$ industry $_{i}$}

$+\beta_{3}$ topic $_{\mathrm{i}}+\beta_{\mathrm{j}}$ control $_{\mathrm{ij}}+\varepsilon$

OPTION \# is a dummy for the respective IFRS policy option; i denotes firm; country, industry, topic, and control denote vectors of variables; and $\varepsilon$ represents the disturbance term. The analyzed accounting options and their coding are displayed in Appendix A. The definitions of the data for the regression analyses and the sources are presented in Appendix B. 
Table 3

Final Sample Per Country and Industry

\begin{tabular}{lccccccccccc}
\hline Country & AT & BE & CZ & DK & FI & FR & DE & IE & IT & LU & NL \\
\hline Consumer Discretionary & 0 & 1 & 0 & 1 & 2 & 18 & 11 & 1 & 5 & 2 & 1 \\
Consumer Staples & 0 & 2 & 0 & 1 & 1 & 4 & 3 & 2 & 1 & 0 & 4 \\
Energy & 1 & 0 & 0 & 0 & 1 & 2 & 0 & 0 & 4 & 0 & 2 \\
Health Care & 0 & 2 & 0 & 6 & 1 & 5 & 7 & 0 & 0 & 0 & 1 \\
Industrials & 1 & 1 & 0 & 4 & 4 & 18 & 13 & 1 & 4 & 0 & 6 \\
Information Technology & 0 & 0 & 0 & 2 & 1 & 5 & 9 & 0 & 1 & 0 & 4 \\
Materials & 1 & 2 & 0 & 2 & 4 & 3 & 11 & 2 & 0 & 1 & 2 \\
Real Estate & 0 & 1 & 0 & 0 & 0 & 5 & 4 & 0 & 0 & 0 & 0 \\
Telecommunications & 0 & 1 & 0 & 1 & 1 & 2 & 4 & 0 & 1 & 0 & 1 \\
Utilities & 0 & 0 & 1 & 1 & 1 & 5 & 4 & 0 & 4 & 0 & 0 \\
\hline Sum & $\mathbf{3}$ & $\mathbf{1 0}$ & $\mathbf{1}$ & $\mathbf{1 8}$ & $\mathbf{1 6}$ & $\mathbf{6 7}$ & $\mathbf{6 6}$ & $\mathbf{6}$ & $\mathbf{2 0}$ & $\mathbf{3}$ & $\mathbf{2 1}$ \\
\hline
\end{tabular}

Table 3

Final Sample Per Country and Industry (Continued)

\begin{tabular}{lcccccccc}
\hline Country & NO & PT & ES & SE & CH & GB & & SUM \\
\hline Consumer Discretionary & 1 & 0 & 1 & 4 & 1 & 22 & & 71 \\
Consumer Staples & 2 & 1 & 2 & 3 & 4 & 8 & 38 & 21 \\
Energy & 3 & 1 & 2 & 1 & 0 & 4 & 38 & 104 \\
Health Care & 0 & 0 & 1 & 2 & 6 & 7 & 33 & 51 \\
Industrials & 0 & 0 & 5 & 13 & 8 & 26 & & 20 \\
Information Technology & 0 & 0 & 1 & 2 & 2 & 6 & 12 & 21 \\
Materials & 2 & 0 & 0 & 4 & 5 & 12 & & 416 \\
Real Estate & 0 & 0 & 0 & 3 & 1 & 6 & & \\
Telecommunications & 1 & 0 & 2 & 2 & 2 & 1 & & \\
Utilities & 0 & 1 & 3 & 0 & 0 & 1 & & \\
\hline Sum & 9 & 3 & $\mathbf{1 7}$ & $\mathbf{3 4}$ & $\mathbf{2 9}$ & $\mathbf{9 3}$ & & \\
\hline
\end{tabular}

Note: This table shows the country and industry distribution of sample firms. The countries are Austria (AT), Belgium (BE), Czech Republic (CZ), Denmark (DK), Finland (FI), France (FR), Germany (DE), Ireland (IE), Italy (IT), Luxembourg (LU), Netherlands (NL), Norway (NO), Portugal (PT), Spain (ES), Sweden (SE), Switzerland (CH), United Kingdom (GB).

\section{Results}

\subsection{Descriptive Results for the Accounting Options}

The analyzed companies use different accounting options heterogeneously. We analyzed two accounting options for the statement of comprehensive income. First, whether the income statement is displayed by nature or by function and second, whether the one statement approach or the two statement approach is used for the statement of comprehensive income. Two third of the analyzed companies (67.79\%) show their income statement by function instead of by nature (Table 4). This result confirms previous findings, such as Stadler and 
Table 4

Accounting Options for the Statement of Comprehensive Income by Country

\begin{tabular}{llccccccccccccc}
\hline $\begin{array}{l}\text { Accounting } \\
\text { option/country }\end{array}$ & & BE & DK & FI & FR & DE & IT & NL & ES & SE & CH & GB & Other & SUM \\
\hline Income statement & Yes & 3 & 4 & 8 & 25 & 20 & 11 & 8 & 14 & 2 & 12 & 16 & 11 & 134 \\
by nature & No & 7 & 14 & 8 & 42 & 46 & 9 & 13 & 3 & 32 & 17 & 77 & 14 & 282 \\
One statement & Yes & 1 & 2 & 1 & 0 & 3 & 0 & 2 & 1 & 9 & 2 & 8 & 2 & 31 \\
approach & No & 9 & 16 & 15 & 67 & 63 & 20 & 19 & 16 & 25 & 27 & 85 & 23 & 385 \\
\hline
\end{tabular}

Note: We aggregated the data for those countries that have a low number of observations. The category "Others" includes companies from AT, CZ, IE, LU, NO, and PT.

Table 5

Accounting Options forthe Statement of Cash Flow by Country

\begin{tabular}{|c|c|c|c|c|c|c|c|c|c|c|c|c|c|c|}
\hline $\begin{array}{l}\text { Accounting } \\
\text { option/country }\end{array}$ & & BE & DK & $\mathbf{F I}$ & FR & DE & IT & NL & ES & SE & $\mathrm{CH}$ & GB & Other & SUM \\
\hline Interest paid in & Yes & 4 & 16 & 16 & 26 & 41 & 12 & 11 & 9 & 15 & 16 & 53 & 15 & 234 \\
\hline $\begin{array}{l}\text { cash flow of oper- } \\
\text { ating activities }\end{array}$ & No & 4 & 0 & 0 & 22 & 22 & 2 & 6 & 6 & 2 & 13 & 32 & 6 & 115 \\
\hline Interest received & Yes & 5 & 15 & 16 & 15 & 44 & 10 & 9 & 9 & 14 & 13 & 33 & 13 & 196 \\
\hline $\begin{array}{l}\text { in cash flow of } \\
\text { operating activi- } \\
\text { ties }\end{array}$ & No & 0 & 0 & 0 & 6 & 14 & 1 & 6 & 5 & 2 & 13 & 51 & 8 & 106 \\
\hline Dividend & Yes & 3 & 5 & 11 & 25 & 26 & 8 & 6 & 8 & 8 & 12 & 19 & 11 & 142 \\
\hline $\begin{array}{l}\text { received in cash } \\
\text { flow of operating } \\
\text { activities }\end{array}$ & No & 1 & 5 & 2 & 16 & 9 & 4 & 10 & 5 & 1 & 6 & 27 & 7 & 93 \\
\hline
\end{tabular}

Nobes (2014) who find similar results for a worldwide sample in 2008/2009. Despite this finding, we can also show that in some jurisdictions the income statements are more frequently displayed by nature. This is especially the case for Spain and Italy. This is due to the fact that the Spanish law of 1989 sets out a by-nature format for the income statement (Kvaal \& Nobes, 2010). The use of this format also has a long-running tradition in Italy (Nobes, 2011).

A sector-specific analysis reveals that especially companies of the telecommunication sector $(84.21 \%$ of those) and the utility sector ( $85.71 \%$ of those) show their income statement by nature, while all of the companies of the health care sector show their income statement by function. The result for the health care sector could be explained by the better opportunity to show the companies' R\&D expenses and its research effort when using the income statement by function.

Regarding the one or the two statement approach, we find a more uniform result (Table 4). Only 31 com- 
panies $(7.45 \%)$ use a one statement approach and display the income statement and the other comprehensive income in one financial statement. It seems that at least for this accounting option the preparers have a certain preference. A sector-specific analysis shows no further insights.

Almost all of the analyzed companies (97.84\%) use the indirect method to display the operating cash flow in the cash flow statement. The limited use of the direct method can be explained by the higher requirements for the companies (another accounting system that is based on cash transactions). It seems to be that under cost-benefit considerations the benefit of a more precise derivation of the operating cash flow is not enough in comparison to the additional costs which arise by implementing an additional accounting system. The empirical result confirms previous findings in that area (e.g., Eisenschmidt \& Schwenkler, 2016; Stadler \& Nobes, 2014; Nobes \& Stadler, 2013).

IAS 7 offers the opportunity to show the dividends and interest paid and received in different categories. Table 5 shows the results for the accounting options for the statement of cash flow differentiated by country. The majority of the analyzed companies (67.05\%) presents the interest paid in the operating cash flow and assumes that these costs are part of their common business. A similar result can be demonstrated for interest received. $64.90 \%$ of the companies show the interest received in the operating cash flow instead of showing it in the cash flow from investing activities. In contrast, the accounting choice for dividends paid is uniform. Only one company presents the dividends paid in the operating cash flow and all the others (394 companies) which disclose such information show them in the financing cash flow. The dividends received are often presented in the operating cash flow. $60.43 \%$ of the companies use the accounting option in that way.

Beside the individual use of the aforementioned accounting options in the cash flow statement, a further analysis is focused on the joint use of three accounting options. IAS 7.33 handles interest received and paid and dividends received in one paragraph and offers the opportunity to display the three items in different parts of the cash flow statement. Therefore, one could argue that the use of these accounting options is interconnected, because they are displayed in the same paragraph. So, a company can maybe use all three options in the same way, for example, displaying all of them in the operating cash flow. Our empirical analysis confirms this assumption partially. 192 companies have all three items in their cash flow statement. $43.75 \%$ of these companies display interest received and paid and dividends received in the operating cash flow.

The country and sector-specific analysis give only a few further insights. In contrast to the average results, $60.71 \%$ of the companies from UK show their interest received in the cash flow from investing activities. We find a similar result for dividends received which are shown in the cash flow from investing activities by $58.70 \%$ of the companies from UK. Two sectors offer different results in comparison to the average findings. More than $50 \%$ of companies from the sector consumer staples present their interest paid in the cash flow of financing activities and their interest received in the cash flow from investing activities. $81.82 \%$ of the companies from the information technology sector display their dividends received in the cash flow from investment activities. Beside the aforementioned findings, there is no much variation in the data which is a substantial constraint for a further regression analysis.

The IASB offers in IAS 16 and IAS 38 the opportunity to measure property, plant and equipment as well as intangible assets at fair value (revaluation model). Nearly all analyzed companies decided to measure property, plant and equipment at cost. Only three companies $(0.73 \%)$ use for some asset groups the revaluation model. One possible explanation for the low acceptance and implementation of the revaluation model could be that there is not enough information about the fair values of certain asset groups. The potential benefit of better (and more informative) accounting numbers (e.g., more assets and equity) goes along with additional costs for generating fair values and applying them in the balance sheet yearly. This additional effort seems to be too high. A similar result can be demonstrated for intangible assets. All of the analyzed companies which have intangible assets (397 companies) measure them at cost. This can be explained by higher requirements for the revaluation model in IAS 38. Often an active market is missing for the intangibles. Therefore, most intangible asset groups cannot be measured at fair value. Our empirical results confirm previous findings in that area (e.g., Eisenschmidt \& Schwenkler, 2016; Christensen \& Nikolaev, 2013; Bahadir \& Tolga, 2013; 
Cairns et al., 2011; Demaria \& Dufour, 2007) and show that the use of accounting options is steady over time.

Another fair value measurement opportunity is in IAS 40. In contrast to the previous results, we can show that $37.21 \%$ of the analyzed companies that have investment properties measure them at fair value. A sector-specific analysis offers additional insights. Nearly all companies from the real estate sector (95\%) use the fair value model of IAS 40 . One reason for this result could be that those companies have the opportunity to show their success out of their investment property decisions and gain additional profit in the income statement which helps to satisfy the investors' profit expectations. The country-specific analysis shows no further insights.

The accounting for government grants is heterogeneous. The majority of the companies which receive government grants show net assets $(63.09 \%)$. The other $36.91 \%$ of the companies recognize them as deferred income on the liabilities side of the balance sheet and release the deferred income to the income statement over the useful life of the related asset. The empirical results show a preference of the preparers for the deduction of the grants from the related assets. One possible explanation could be that a deduction is easier to handle in the accounting system of the company. Once the amount is received, it will be deducted from the related asset and then no further procedures have to be done anymore. The sector and country-specific analysis reveal no further insights.

Inventory costs can be measured by FIFO or by weighted average. $31.21 \%$ of the analyzed companies use only the FIFO method for inventory costs. The other $68.79 \%$ use only weighted average or weighted average and FIFO. The country-specific analysis shows that $71.43 \%$ of the Danish companies and $68.00 \%$ of the Swedish companies use only the FIFO method, while $96.23 \%$ of the German companies use weighted average or both methods for inventory costs. The findings regarding the German approach is in line with, for instance, Stadler and Nobes (2014) and Nobes and Stadler (2013) studies. The sector-specific analysis shows only for the sector utilities a substantial result. In this sector, solely $4.76 \%$ of the companies use only the FIFO method for inventory costs.

The empirical results for all analyzed accounting options are displayed in Table 6. The results show a clear preference of the preparers for the use of some accounting options, that is, topic 2, topic 3, topic 6 , topic 8 , topic 9 . That increases the comparability of the financial statements which is desirable from the perspective of the financial statements' users. However, the missing variability in the data limits further empirical work. If the depending variable (the accounting choice) does not vary between the companies, logistic regression will fail. Therefore, we can only work with these accounting options which are not uniformly used by the prepares.

\subsection{Influence Factors for the Accounting Options}

The results of the regression analyses are displayed in Table 7. The reductions in the respective sample size result from missing data in the Worldscope database. We can demonstrate for all analyses a significant model (1\%-level). Thus, the derived models are better than the models which only have the intercept and none of our exogenous variables. The explanatory power is moderate. We find for some regressions a very high Nagelkerke R-squared of more than 50\%, for example, option 1 (income statement by nature) and option 10 (investment properties at cost), while other regression models achieve only lower values, for example, option 11 (government grants deducted from assets). Besides, the models classify at least two-third of the cases perfectly.

The country variables are only in some regressions significant. We can demonstrate for example that UK companies more often present the income statement by function instead of by nature. The result is significant at the $1 \%$ level and is in line with the results of our univariate analysis. In contrast, there are three models (option 5, option 10 and option 11 in Table 7) where country factors have no significant impact on the accounting choice. Therefore, we cannot conclude out of our European sample that country effects have always an impact on accounting choices.

We find similar results for our sector variables. Some models show a significant impact of the industry on the accounting choice (e.g., the model for option 1 in Table 7), while other models reveal no impact (e.g., the model for option 10). The same result can be demonstrated for the respective topic variables. Three of the seven models show a significant impact of the topic variable on the accounting choice (i.e. option 1, option 5 , and option 7), while the topic variables in the other 


\section{Table 6}

Summary of Empirical Results Regarding the Accounting Options

\begin{tabular}{|c|c|c|c|c|}
\hline Topic & Accounting option & & Number of firms & Percentages \\
\hline \multirow[t]{2}{*}{1} & Income statement by nature (416 observations) & Yes & 134 & 32.21 \\
\hline & & No & 282 & 67.79 \\
\hline \multirow[t]{2}{*}{2} & One statement approach for income statement & Yes & 31 & 7.45 \\
\hline & (416 observations) & No & 385 & 92.55 \\
\hline \multirow[t]{2}{*}{3} & Indirect method for operating cash flow & Yes & 407 & 97.84 \\
\hline & (416 observations) & No & 9 & 2.16 \\
\hline \multirow[t]{2}{*}{4} & Interest paid in operating cash flow ( 349 observa- & Yes & 234 & 67.05 \\
\hline & tions) & No & 115 & 32.95 \\
\hline \multirow[t]{2}{*}{5} & Interest received in operating cash flow & Yes & 196 & 64.90 \\
\hline & (302 observations) & No & 106 & 35.10 \\
\hline \multirow[t]{2}{*}{6} & Dividends paid in finance cash flow & Yes & 394 & 99.75 \\
\hline & (395 observations) & No & 1 & 0.25 \\
\hline \multirow[t]{2}{*}{7} & Dividends received in operating cash flow & Yes & 142 & 60.43 \\
\hline & (235 observations) & No & 93 & 39.57 \\
\hline \multirow[t]{2}{*}{8} & Property, plant and equipment at cost & Yes & 410 & 99.27 \\
\hline & (413 observations) & No & 3 & 0.73 \\
\hline \multirow[t]{2}{*}{9} & Intangibles at cost ( 397 observations) & Yes & 397 & 100.00 \\
\hline & & No & 0 & 0.00 \\
\hline \multirow[t]{2}{*}{10} & Investment property at cost ( 86 observations) & Yes & 54 & 62.79 \\
\hline & & No & 32 & 37.21 \\
\hline \multirow[t]{2}{*}{11} & Governments grants deducted from assets & Yes & 94 & 63.09 \\
\hline & (149 observations) & No & 55 & 36,91 \\
\hline \multirow[t]{2}{*}{12} & FIFO only (314 observations) & Yes & 98 & 31.21 \\
\hline & & No & 216 & 68.79 \\
\hline
\end{tabular}

four models have no significant impact. The amount of selling, general, and administrative expenses influences for example significantly the choice of presenting the income statement by nature (option 1).

The companies' size has a significant impact on the presentation of interest and dividends in the cash flow statement. We can show that larger companies show their interest paid and received as well as the dividend received in the cash flow from operating activities (option 4 , option 5 , and option 7 ). The dividend yield has explanatory power for option 4 , option 7 , and option 12 (see Table 7).

As robustness check, we calculated the different regressions with natural logarithm of sales as proxy for size. We find nearly the same results, but the explanatory power of the different models is slightly lower. Thus, we can conclude that changes in the research setting do not alter the results and there is no bias out of using a market variable as proxy for size.

The analysis of the odds ratios shows a very high impact of some country variables in the different models. The highest odd ratio for option 1 has the country variable Spain, for option four the country variable France, for option 11 the country variable Spain, and for option 12 the country variable Germany. It seems to be that the country variables have a stronger influence on the accounting choice than the industry or the topic variables.

Our results confirm the previous work of Stadler and Nobes (2014) which show for other jurisdictions (an international sample containing $\mathrm{AU}, \mathrm{CH}, \mathrm{CN}, \mathrm{DE}$, ES, FR, GB, HK, IT, ZA) in the fiscal year 2008 similar results. They also find a significant influence of country, industry, and topic variables for their sample in some of 
Table 7

Results of the Regression Analyses

\begin{tabular}{|c|c|c|c|c|c|c|c|}
\hline Country & $\begin{array}{c}\text { Option } 1 \\
\text { (Income } \\
\text { state-ment } \\
\text { by nature) }\end{array}$ & $\begin{array}{c}\text { Option } 4 \\
\text { (Interest paid } \\
\text { in operating } \\
\text { cash flow) }\end{array}$ & $\begin{array}{l}\text { Option } 5 \\
\text { (Interest } \\
\text { received in } \\
\text { operating } \\
\text { cash flow) }\end{array}$ & $\begin{array}{c}\text { Option } 7 \\
\text { (Dividends } \\
\text { received in } \\
\text { operating cash } \\
\text { flow) }\end{array}$ & $\begin{array}{l}\text { Option } 10 \\
\text { (Investment } \\
\text { property at } \\
\text { cost) }\end{array}$ & $\begin{array}{l}\text { Option } 11 \\
\text { (Govern- } \\
\text { ments grants } \\
\text { deducted } \\
\text { from assets) }\end{array}$ & $\begin{array}{l}\text { Option } 12 \\
\text { (FIFO } \\
\text { only) }\end{array}$ \\
\hline $\mathrm{BE}$ & -1.861 & 1.500 & -1.071 & -1.759 & -1.949 & -1.356 & 0.230 \\
\hline DK & $-2.650^{*}$ & -19.117 & -20.360 & 1.683 & dropped & -1.058 & -1.266 \\
\hline FI & -0.012 & -20.308 & -21.314 & -20.761 & -19.065 & -1.323 & 0.069 \\
\hline FR & $-1.867^{* *}$ & $1.641^{* *}$ & 0.754 & 0.935 & -1.973 & -0.045 & $1.186^{*}$ \\
\hline $\mathrm{DE}$ & -1.079 & $1.130^{*}$ & -0.029 & -1.256 & -1.200 & -0.468 & $3.746^{\star * *}$ \\
\hline IT & -0.414 & -0.457 & -0.873 & -0.825 & -1.245 & -0.174 & 1.236 \\
\hline NL & -0.518 & 0.575 & -0.531 & -0.155 & -19.758 & -1.743 & 0.338 \\
\hline ES & 2.176 & 0.708 & -0.580 & -0.380 & -2.440 & 1.236 & $2.083^{\star}$ \\
\hline SE & -22.383 & 0.508 & -0.698 & -1.376 & 3.446 & -0.134 & -1.139 \\
\hline $\mathrm{CH}$ & -0.478 & $1.274^{*}$ & 0.332 & -1.500 & 0.889 & -0.068 & 0.726 \\
\hline GB & $-3.799^{* * *}$ & 0.733 & 0.906 & $1.552^{* *}$ & -0.368 & -0.044 & 0.472 \\
\hline Consumer Discretionary & $-5.338^{* * *}$ & -0.184 & -0.569 & $-1.751^{\star}$ & -0.663 & -0.730 & -1.595 \\
\hline Consumer stables & $-4.777^{* * *}$ & $1.590^{* *}$ & 1.153 & -0.148 & -1.668 & -0.700 & -1.023 \\
\hline Energy & $-3.533^{* * *}$ & 1.050 & -0.054 & -0.800 & 1.010 & -21.898 & -1.063 \\
\hline Health Care & -28.804 & 0.074 & 0.004 & 1.178 & -21.202 & -0.393 & $-2.058^{\star}$ \\
\hline Industrials & $-3.417^{* * *}$ & 0.730 & 0.149 & -0.343 & -2.480 & -0.865 & -1.577 \\
\hline Information Technologies & $-5.308^{* * *}$ & 0.746 & 0.868 & 39.034 & dropped & 0.983 & $-3.144^{* *}$ \\
\hline Materials & $-4.537^{* * *}$ & 0.695 & 0.609 & -0.992 & -1.687 & -0.678 & -0.445 \\
\hline Real Estate & -2.025 & -0.201 & $-2.428^{*}$ & 0.429 & 2.943 & -0.932 & dropped \\
\hline Telecommunications & -0.523 & -0.647 & $-2.226^{*}$ & -1.391 & 22.002 & $-2.338^{*}$ & -1.368 \\
\hline Topic variables (deciles) & $0.202^{* *}$ & 0.031 & $0.143^{* *}$ & $0.174^{* *}$ & -0.137 & -0.010 & -0.021 \\
\hline SIZE & 0.022 & $0.312^{* *}$ & $0.387^{* *}$ & $0.427^{* *}$ & 0.424 & 0.146 & -0.178 \\
\hline DIVYIELD & -0.008 & $-0.183^{\star *}$ & -0.082 & $0.347^{* *}$ & 0.078 & 0.113 & $-0.302^{* * *}$ \\
\hline Intercerpt & 2.695 & 25.107 & 39.517 & -20.676 & 38.421 & 31.478 & 6.915 \\
\hline $\mathrm{p}$-Value & 0.000 & 0.000 & 0.000 & 0.000 & 0.000 & 0.000 & 0.000 \\
\hline Nagelkerke R-squared & 0.574 & 0.244 & 0.410 & 0.486 & 0.683 & 0.195 & 0.375 \\
\hline$\%$ classified correctly & 86.34 & 71.03 & 74.52 & 75.42 & 82.14 & 68.75 & 76.49 \\
\hline Observations & 322 & 321 & 259 & 179 & 84 & 14 & 302 \\
\hline Observation dropped & 94 & 28 & 43 & 56 & 2 & 5 & 12 \\
\hline Topic variable & ADMEXP/S & INTPAID/S & INTRC/S & DIVREC/S & PPEG/A & $\mathrm{EQU} / \mathrm{A}$ & INVEN/A \\
\hline
\end{tabular}


their models (but not in all). Thus, we can conclude that these factors are still relevant in explaining the different use of accounting options. We extend their empirical work by current results and confirm them for a different (only European) sample.

\section{Conclusion}

Worldwide accounting standardization through the adoption of IFRS is one of the most stimulating events in corporate financial reporting over the last 15 years (Procházka, 2017). IFRS are now considered as the global accounting standards (Ajili \& Bouri, 2017; Firoz, 2011), and about 140 nations and reporting authorities permit or require their use for domestic listed companies (Eisenschmidt \& Krasodomska, 2017).

Our study covers 17 European countries which use IFRS, including 15 EU Member states, Norway and Switzerland. As we were able to investigate, despite the IASB substantial efforts to harmonize the accounting practices, differences in these countries' reporting remain. Our paper explores them and the reasons why they exist. According to our study results, there are accounting options preferred by the companies, such as an indirect method for operating cash flow, dividend paid in finance cash flow, valuation of property, plant and equipment as well as intangibles at cost. As far as the factors influencing their choices are concerned, we are not able to confirm that country, industry and topic variables have a significant influence on corporate decisions. Therefore, our hypotheses are not supported. However, the country variables seem to have a stronger influence on the accounting option choices than industry or topic variables. This finding is in line with other studies, for instance, Jaafar and McLeay (2007) or Stadler and Nobes (2014).

We differ from prior literature because our study's setting features countries from the same European region, using the same international standards. Many papers published so far took a world perspective (e.g., Kvaal \& Nobes, 2010, 2012; Nobes, 2011; Nobes \& Perramon, 2013; Nobes \& Stadler, 2013, 2015).

We believe that the present study contributes to the literature on accounting options. We were able to confirm the results of previous studies with the use of data for the financial year 2017 and a large sample (as regards the countries representation and the number of firms). It is worth noting that there have been significant efforts by the IASB and its predecessor body to remove accounting policy choices since the prior studies. In our study, we follow the approach of Stadler and Nobes (2014) which was based on the financial data from 2008. In contrary to our expectations, 11 years later, the accounting practices in Europe are still not very different. Country specific factors still have strong influence on the accounting option choice and therefore can be seen as an obstacle in the successful accounting harmonization.

Our results are informative about preparers' choices under IFRS and thus are relevant to informing capital market participants about the way IFRS are being used. New IFRS preparers can use the empirical results regarding the accounting option choice as a benchmark for their own reporting. Moreover, the results might be useful to improve the understanding of how country, industry or topic influence the firms' decisions to use accounting options. They also provide guidance for other researchers which variables and measures might be considered in future studies of various accounting policy choices. The study also has some significant policy implications. It provides new insights into use of accounting options for some topics which potentially reduce the comparability of accounting information across firms, industries and countries. This information might be useful for the national standard setters in Europe and IASB itself.

Like other studies, this study is not free from limitations. We focus on accounting choices which are clearly observable. For covert choices, the study results might be different. A further limitation is that we could have underestimated the influence of topic factors if we did not identify the most appropriate topic variables. Some of our models have a low explanatory power. This implies that there are maybe other factors that influence the accounting option choice (omitted variable bias). Besides, other European samples and/or other periods analyzed can lead to different results.

The authors believe that accounting policy choice is an interesting topic and requires further investigation. Future research could include new countries, especially from Central and Eastern Europe, since this part of the European region is under-researched with regard to the use of accounting options. Future researchers may also use other research approaches (such as interviews) to deepen the knowledge on the management decision regarding the IFRS accounting option choices. Another research question could address the impact of the different use of accounting options. If the use of accounting options change 
accounting numbers that could have an impact on stock prices and investors' returns. Overall, this research topic offers quite a lot of potential for future research projects and researchers are invited to participate in that area.

\section{References}

Ajili, H., \& Bouri, A. (2017). Comparative study between IFRS and AAOIFI disclosure compliance: evidence from Islamic banks in Gulf Co-Operation Council countries. Journal of Financial Reporting and Accounting, 15(3), 269-292. https:// doi.org/10.1108/JFRA-03-2016-0023

Albu, N., \& Albu, C. N. (2014). IFRS Application in Central and South-Eastern European Countries. Accounting \& Management Information Systems, 13(2), 182-197.

Aledo, J., García-Martínez, F., \& Marín Diazaraque, J. M. (2009). Firm-specific factors influencing the selection of accounting options provided by the IFRS. Working Paper series at the Bank of Spain, Documentos de Trabajo N. ${ }^{\circ}$ 0926, Madrid, 1-39. http://dx.doi.org/10.2139/ssrn.1521474

Bahadir. O., \& Tolga, B. (2013). Accounting policy options under IFRS: Evidence from Turkey. Accounting and Management Information Systems, 12(3), 388-404. Retrived from https://EconPapers.repec. org/RePEc:ami:journl:v:12:y:2013:i:3:p:388-404

Cairns, D., Massoudi, D., Taplin, R., \& Tarca, A. (2011). IFRS fair value measurement and accounting policy choice in the United Kingdom and Australia. The British Accounting Review, 43, 1-21. https:// doi.org/10.1016/j.bar.2010.10.003

Christensen, H. B., \& Nikolaev, V. V. (2013). Does fair value accounting for non-financial assets pass the market test? Review of Accounting Studies, 18(3), 734-775. https://doi.org/10.1007/s11142-0139232-0

Demaria, S., \& Dufour, D. (2007). First time adoption of IFRS, Fair value option, Conservatism: Evidences from French listed companies, paper presented at $30^{\text {th }}$ European Accounting Association Congress, 25-27 April 2007, Lisbon, Portugal. https://halshs. archives-ouvertes.fr/halshs-00266189/document

Eisenschmidt, K., \& Krasodomska, J. (2017). Insights into the IASB due process: the influence of country characteristics on constituents' formal participation. Theoretical Journal of Accounting, 95(151), 117-145. https://doi. org/10.5604/01.3001.0010.6570

Eisenschmidt, K., \& Schwenkler, F. (2016). Zur Nutzung von expliziten Wahlrechten nach IFRS
- Eine empirische Analyse für die Unternehmen des HDAX und SDAX [The use of explicit voting rights on IFRS - an empirical analysis of the HDAX and SDAX companies]. Zeitschrift für internationale und kapitalmarktorientierte Rechnungslegung [Journal of International and Capital Market Oriented Accounting] 16(2), 53-59.

Firoz, M. (2011). IFRS - preparedness of Indian banking industry. Journal of Financial Reporting and Accounting, 9(1), 47 - 53. https://doi. org/10.1108/19852511111139796

Guermazi, W., \& Khamoussi, H. (2018). Mandatory IFRS adoption in Europe: Effect on the conservative financial reporting. Journal of Financial Reporting and Accounting, 16(4), 543-563. https:// doi.org/10.1108/JFRA-08-2017-0070

Haller, A., \& Wehrfritz, M. (2013). The impact of national GAAP and accounting traditions on IFRS policy selection: Evidence from Germany and the UK. Journal of International Accounting, Auditing and Taxation, 22, 39-56. https://doi.org/10.1016/j. intaccaudtax.2013.02.003

Inchausti, B. G. (1997). The influence of company characteristics and accounting regulation on information disclosed by Spanish Firms. European Accounting Review, 6(1), 45-68. https://doi. org/10.1080/096381897336863

Jaafar, A., \& McLeay, S. (2007). Country Effects and Sector Effects on the Harmonization of Accounting Policy Choice. Abacus, 43(2), 156-189. https:// doi.org/10.1111/j.1467-6281.2007.00224.x

Klumpes, P. J. M., \& Whittington M. (2003). Determinants of actuarial valuation nethod changes for pension funding and reporting: Evidence from the UK. Journal of Business Finance and Accounting, 30(1-2), 175-204. https://doi.org/10.1111/14685957.00488

Krippendorff, K. (2012). Content analysis: An introduction to its methodology. Sage Publications.

Kvaal, E., \& Nobes, Ch. (2010). International differences in IFRS policy choice: A research note. Accounting and Business Research, 40(2), 173-187. https:// doi.org/10.1080/00014788.2010.9663390

Kvaal, E., \& Nobes, Ch. (2012). IFRS policy changes and the continuation of national patterns of IFRS practice. European Accounting Review, 21(2), 343371. https://doi.org/10.1080/09638180.2011.611 236

Lombard, M., Snyder-Duch, J., \& Bracken, C.C. (2002). Content analysis in mass communication: Assessment and reporting of intercoder reliability. Human Communication Research, 28(4), 587- 
604. https://doi.org/10.1111/j.1468-2958.2002. tb00826.x

Lourenco, I. C., Sarquis, R., Branco M. C., \& Pais, C. (2015). Extending the classification of European countries by their IFRS practices: A research note. Accounting in Europe, 12(2), 223-232. https://doi. org/10.1080/17449480.2015.1111520

Morris, R.D., \& Gordon, I. (2006). Equity accounting adoption in regulated and unregulated settings: An empirical study. Abacus, 42(1), 22-42. https:// doi.org/10.1111/j.1467-6281.2006.00187.x

Nobes, Ch., \& Stadler, Ch. (2013). How arbitrary are international accounting classifications? Lessons from centuries of classifying in many disciplines, and experiments with IFRS data. Accounting, Organizations and Society, 38, 573-595. https://doi. org/10.1016/j.aos.2013.10.001

Nobes, Ch., \& Stadler, Ch. (2015). The qualitative characteristics of financial information, and managers' accounting decisions: Evidence from IFRS policy changes. Accounting and Business Research, 45(5), 572-601. https://doi.org/10.1080/00014788.2015. 1044495

Nobes, Ch. (2006). The survival of international differences under IFRS: towards a research agenda. Accounting and Business Research, 36(3), 233-245. https://doi.org/10.1080/00014788.2006.9730023

Nobes, Ch. (2011). IFRS practices and the persistence of accounting system classification. Abacus, 47(3), 267-83. https://doi.org/10.1111/j.14676281.2011.00341.x

Nobes, Ch., \& Perramon, J. (2013). Firm size and national profiles of IFRS policy choice. Australian Accounting Review, 66(23), 208-215. https://doi. org/10.1111/j.1835-2561.2012.00203.x

Procházka, D. (2017). The unintended consequences of accounting harmonization in a transition country: A case study of management accounting of private Czech companies. Contemporary Economics, 11(4), 443-458. https://doi.org/10.5709/ ce.1897-9254.255

Stadler, Ch., \& Nobes, Ch. (2014). The influence of country, industry, and topic factors on IFRS policy choice. Abacus, 50(4), 386-421. https://doi. org/10.1111/abac. 12035

\section{Acknowledgments:}

We thank Andreas Bytof, Cora Flathmann, Leif Jansen, Christina Lücht, Sven Peterson, and Vanessa Rother for their support in the content analysis of the annual reports. We would like to thank the participants of the Trends in Accounting Research Conference 2019, in Kiel, Germany, and the 9th International Conference Financial Reporting and Auditing in Kraków, Poland, for their helpful comments, as well as two anonymous reviewers whose suggestions allowed us to improve and clarify this manuscript. This work was supported by the Ministry of Science and Higher Education, Poland under Grant no. 27/EFR/2020/POT. 


\section{Appendix A: Coding of accounting options}

Option 1: Income statement by nature or by function (IAS 1.99); if the income statement is by nature than it is coded with the value 1 , otherwise 0

Option 2: One statement approach vs. two statement approach for the income statement and the statement of the other comprehensive income (IAS 1.10A); if there is an one statement approach, it is coded with the value 1 , otherwise 0

Option 3: Direct or indirect method for the operating cash flow (IAS 7.18); if the indirect method is used for calculating and presenting the operating cash flow in the cash flow statement, it is coded with the value 1 , otherwise 0

Option 4: Presentation of interest paid in the cash flow statement (IAS 7.33); if the inter-est paid is presented in the operating cash flow, it is coded with the value 1 , otherwise 0

Option 5: Presentation of interest received in the cash flow statement (IAS 7.33); if the interest received is presented in the operating cash flow, it is coded with the value 1 , otherwise 0

Option 6: Presentation of dividend paid in the cash flow statement (IAS 7.34); if the div-idend paid is presented in the cash flow of financing activities, it is coded with the value 1 , otherwise 0

Option 7: Presentation of dividend received in the cash flow statement (IAS 7.33); if the dividend received is presented in the cash flow of operating activities, it is cod-ed with the value 1 , otherwise 0

Option 8: Cost model or revaluation model for property, plant and equipment (IAS 16.29); if the measurement method for property, plant and equipment is the cost model in the notes, it is coded with the value 1 , otherwise 0 ; companies that use both methods are coded under zero as well

Option 9: Cost model or revaluation model for intangibles (IAS 38.72); if the measure-ment method for intangibles is the cost model in the notes, it is coded with the value 1 , otherwise 0

Option 10: Investment property at cost (IAS 40.30); if the measurement method for in-vestment properties is at cost in the notes, it is coded with the value 1 , other-wise 0
Option 11: Government grants deducted from assets (net assets) or not (IAS 20.24); if government grants are deducted from assets in the notes, it is coded with the value 1 , otherwise 0

Option 12: Inventory costing using FIFO method or weighted average method (IAS 2.25); if the inventory costing method is only FIFO in the notes, it is coded with the value 1 , otherwise 0 ; companies that use both methods are coded under zero as well 


\section{Appendix B: Definitions of variables}

Data sources, including Worldscope codes, are shown in square brackets.

Option variables:

OPTION \# Dummy for the respective option for each of the 12 IFRS accounting options (see Appendix A), for example, OPTION 1 is the variable for the presentation of the income statement: 1 for income statement by na-ture and 0 otherwise [handcollected]

\section{Country variables:}

Dummy for the respective country (abbreviations are according to the ISO 3166-1 al-pha-2 code): Austria (AT), Belgium (BE), Czech Republic (CZ), Denmark (DK), Fin-land (FI), France (FR), Germany (DE), Ireland (IE), Italy (IT), Luxembourg (LU), Netherlands (NL), Norway (NO), Portugal (PT), Spain (ES), Sweden (SE), Switzer-land (CH), United Kingdom (GB). Countries with a low number of observations were aggregated in the category 'Others'. The category "Others" includes companies from AT, CZ, IE, LU, NO, and PT.

\section{Industry variables:}

Dummy for the respective industry classification of the STOXX Europe 600 (supersec-tor): consumer discretionary, consumer staples, energy, health care, industrials, infor-mation technology, materials, real estate, telecommunications, utilities
Topic variables (only displayed for those accounting options that were part of the regression analyses):

Option 1: ADMEXP/S (Selling, general, and administrative expenses / sales), [WC01101/WC01001]

Option 4: INTPAID/S (i.e., Interest paid / sales), [WC04148/WC01001]

Option 5: INTREC/S (i.e., Interest received / sales), [WC04149/WC01001]

Option 7: DIVREC/S (i.e., Dividend received / sales), [WC04052/WC01001]

Option 10: PPEG/A (i.e., Property, plant, and equipment (gross) / total assets, [WC02301/WC02999]

Option 11: EQU/A (i.e., Total shareholders' equity / total assets), [WC03995/WC02999]

Option 12: INVEN/A (i.e., Inventories / total assets), [WC02101/WC02999]

Control variables:

SIZE Natural logarithm of market capitalization (in Euro) as of 31st December 2017, [WC08001]

DIVYIELD Dividend yield as of 31st December 2017, [WC09404] 